\title{
An engagement from a puritan theology perspective on some dominant ideas held by the contemporary culture on work, vocation and calling
}

\author{
Ben Geoffrey A S
}

Madras Christian College, Chennai 600 059, Tamil Nadu, India

Corresponding author email : bengeof@gmail.com

ORCID ID : 0000-0001-6545-6314

\begin{abstract}
The reformers, Luther and others protested against the Roman Catholic theology that allegedly created a wedge between sacred and secular vocations and glorified the sacred at the cost of demeaning and devaluing the secular. However with the dawn of modernity, many individualistic ideas of work, vocation and calling have risen in the culture that goes against Protestant/Puritan thought in many ways yet the Protestant theology is in many ways blamed for the rise in individualism. Therefore this article weighs in with some Christian reflection from a puritan theology perspective over some contemporary ideas held by the culture concerning work, vocation and calling from a protestant perspective in an attempt to reclaim truly puritan thinking on these matters of work, vocation and calling
\end{abstract}




\section{Introduction}

The protestant concept of vocation was a protest against Roman Catholic theology that allegedly created a wedge between sacred and secular vocations and glorified the sacred at the cost of demeaning and devaluing the secular. The reformers claimed that not only sacred but also the secular vocations served in its purpose to fulfil God's plans and purposes. Luther said that

"The entire world is full of service to God, not only the churches but also the home, the kitchen, the cellar, the workshop, and the field of the townsfolk and farmers." [1]

The systematic treatment of the protestant concept of work, vocation and calling was carried out in the 'A Treatise on Vocations' by the English Puritan William Perkins. However with the dawn of modernity, many individualistic ideas of work, vocation and calling have risen in the culture that goes against Protestant Christian thought in many ways yet Protestant theology is in many ways blamed for the rise in individualism [2]. Therefore this article weighs in with some Christian reflection over some contemporary ideas held by the culture concerning work, vocation and calling from a protestant perspective in an attempt to reclaim truly protestant Christian thinking on these matters of work, vocation and calling

\section{Is Protestantism to blame for rise in individualism ?}

God has gifted humans with the ability to work (Deut. 8:18) and also grants them the gift to eat of the fruit of their labour (Eccles. 5:18-20) that they may give thanks and praise to God the giver of good gifts and life (Jam. 1:17). Secular vocations like rulers, lawyers and doctors are employed toward the ends of our earthly well-being and flourishing and in religious vocations like Bible teachers, pastors; God appoints them here on earth to administer to us matters concerning our eternal well-being. In such flourishing and wellness, God's goodness is displayed and God is glorified. Towards this end no human being can function as a lone ranger but pursue it as a group, for groups are stronger and achieve more than the individual. For this reason Aristotle reminds us in his politics that no one human being is self-sufficing on his own. He says that

"The proof that the state is a creation of nature and prior to the individual is that the individual, when isolated, is not self-sufficing; and therefore he is like a part in relation to the whole. But he who is unable to live in society, or who has no need because he is sufficient for himself, must be either a beast or a god: he is no part of a state." [3] 
God being maximally good and His moral law being consistent with His own nature would thus require human beings by his moral standards to direct their actions toward the end of highest possible wellness, flourishing and goodness which is achieved only by groups and not individual lone rangers. Therefore the puritan Perkins in his treatise on vocations talks about how God has required by His moral law our collective enterprise wherein different people play different roles with different gifts and talents at different hierarchical levels and bring about the collective good of the church and the state or the commonwealth [4]. The New Testament also teaches that each person is part of a larger whole (1 Cor. 12:12-27) and that one should do nothing out of selfish ambition (Phil. 2:3-4). However the present age seems to be characterized by individualism and completely devoid of collective thinking. This can be observed at many levels. The tech giant Linus Torvalds in his autobiography talks about how one should make a living by making a contributing to human flourishing, producing goods or service that in some way makes a contribution to human flourishing and from the collective good draw his personal good as proportionate to his labour. However sadly what happens is powerful people misguided by the arrogance power breeds in depraved humans foolishly think they can thwart the common good in service of their personal good. However no individual no matter how powerful can be more powerful than the group, for in him seeking his personal good he sets himself against so many people whose personal good is set against his and in them seeking their collective good form a united position against him to overthrow him eventually. History is replete with such lessons from roman slave insurrections to peasant uprisings against the feudal hierarchy in the French revolution $[5,6]$. Linus narrates a more recent instance where big corporations have tried to control the market and failed. He says

"The way to survive and flourish is to make the best damn product you can. And if you can't survive and flourish on that, then you shouldn't. If you can't make a good car, then you deserve to go down like the rock that was the U.S. auto industry in the 1970s. Success is about quality and about giving folks what they want. It's not about trying to control people. The trouble is, people and companies are too often motivated by pure greed. And that always causes them to lose in the long run. Greed leads to decisions governed by paranoia and a need for total control. Those are bad, short-sighted decisions that end up in disaster, or near disaster. The simple example on everyone's mind has been the phenomenal early success of wireless technology in Europe at the expense of American companies. While the U.S. companies individually tried to control the market by using their own proprietary standards, the European companies rallied around a single standard, GSM, and chose to compete based on which company could produce the best product and provide the best service. The U.S. companies have fallen behind, plagued by their own competing standards. With a market buoyed by a common standard, the European companies have all shared in the boom. That's why 
kids in Prague were swapping cell-phone text messages years before kids in Peoria had even heard about it as a new way of cheating on tests." [7]

These things must tell us that the personal good can only be secured along with the common good; the personal good that comes at the expense of the common good is sure expected to fail and bring ruin. One can also point out self-seeking attitudes and self-serving interests on how Parents want to set their children up with work as F.Devine in his book 'Class practices: How parents help their children get good jobs' observes how Parents want to educate their children to the most secure and well-paid jobs[8]. The young too are wooed in the direction of self-serving goals with the self-help and life teachers asking them to follow their passions in identifying their calling, as career is now identified as a path to selffulfilment [9]. What kind of a society could effectively function if supposing medical profession is the best paid and secure job and if everyone was trying to be a Doctor? Don't we need farmers to produce our food, traders to buy and sell them, skilled workmen in different areas, jurists to secure the rule of just law and statesman to rule justly over us. If one could think of one's work and vocation so individualistically as the culture makes it to be, as to follow one's passion is the way of identifying one's calling, then what if being a Rock star or a footballer was vogue at one moment and if everyone is passionate about being a Rock star what kind of a society could function that way? This is the reason in Paul's understanding in 1 Cor. 12:12-27, people with different talents play different roles and functions and are all united under the headship of Christ. Just like the hand cannot say to the leg, I don't need you. The doctor cannot say to the farmer I don't need you and the scientist cannot say to the artist I don't need you. Thus the Puritan view of vocations and calling is that many roles and functionalities are required to be played in a society for its wellness and flourishing that comes by living according to the laws and statutes of God and God by providentially distributing different gifts and talents calls each one unto his calling by the necessity of each role. Thus the puritan William Perkins says

"The common good of men stands in this, not only that they live, but that they live well, in righteousness and holiness, and consequently in true happiness. And for the attainment hereunto, God has ordained and disposed all callings, and in his providence designed the persons to bear them."[4]

It is true that when Luther proclaimed 'Here I stand, my conscience is captive to the word of God' [10] he began the revolution of privatization of religion and morality while putting an end to state sanctioned morality and state defined common good stamped with the authority of the church which according to the protestant reformers mostly served the personal good of the ruling political and religious aristocracy than the common good of the populace. Post Luther Protestants have acknowledged this caution against the dangers of power concentration in the context of human depravity. The will which is not neutral with respect to 
good or evil but is predisposed to evil according to Luther's thesis on 'The Bondage of the Will'[11]. Excessive power empowers the will in its predisposed direction toward evil and self serving interests rather than the common good. Therefore in protestant theology and preaching that has been pro-free enterprise and pursuit of the personal good and advocacy for limited government has only been so as a caution against the dangers of power concentration and not to promote the pursuit of the personal good divorced from the common good [12]. For if it in anyway promotes the pursuit of purely personal good or selfish ambition, it will cease to be protestant, for the authority of scripture forbids selfish ambition (Phil 2:3-4). Therefore protestant theology can be thought of as private determination of the common good and identifying one's roles by gifts, talents and opportunities as distributed by the Hand of providence and faithfully and dutifully carrying out those roles to bring about the common good, flourishing and wellness through which God's goodness is displayed and the giver of all gifts, the ability to work and the One who establishes the work of our hands is glorified in receiving thanks and praise.

To be an individual and to get involved in an activity to secure the common good as a community is God's great gift to man. However even if man forgets that he is a social animal and becomes individualistic, God providentially secures his design of a social world in the following way, that without the strength of the community, the individualistic forces are conquered by collectivistic forces just like how the hunters, gatherers and nomads were conquered or were replaced by the more collectively organized civilizations. [13]

\section{A Puritan reflection on modern social egalitarianism}

Modern egalitarian thought tends to see hierarchy as unnecessary or sometimes even evil [14]. However such a thought is Biblically not supported. The Bible teaches it is God who has placed some men in power and others as subjects to be ruled over(Rom 13, 1 Pet 2:1325 ), for if power was not concentrated in few hands to rule there is anarchy and chaos and order is lacking. Therefore it follows that in view of the common good that these persons are treated as their position in the hierarchy demands and deserves. For example, the time of a governor who rules a million subjects should be treated with more respect than somebody else lower in the social hierarchy.

The Bible also teaches that the wealth and land that concentrates in the hands of the master is also providentially for good purposes, so that when others serve the rule of the master and work their hands on the wealth of the master that may be in the form of land, industry establishment, etc. Then there is growth, creation of new jobs and industry, flourishing, 
wellness and a furthering of the common good. This is the reason William Perkins teaching in view of the common good, says

"persons are distinguished by order, whereby God has appointed that in every society, one person should be above or under another — not making all equal, as though the body were to be all head and nothing else — but in degree and order, he has set a distinction that one should be above another (Rom 13.7; 1Pet 2.13,14).'[4]

\section{A Puritan reflection - Did God mean for us to retire from work as early as possible?}

Modernity seems to sell the apparently lucrative idea that one could work yourself enough prosperity to retire as early as possible and spend one's life enjoying holidays for the rest of one's life [15]. Firstly this goes against puritan theology of stewardship[16], where more the wealth gained more the responsibility to use it responsibly in the view of the common good out of which we draw our personal good proportionate to our labour, for Jesus says 'To whom much is given much is expected' and that 'the workman deserves his wages'. It is important to make distinction between protestant idea of stewardship of wealth and authority where one is to give account to God of its responsible usage in view of the common good/human flourishing with modern epicurean individualism that sees accumulating more wealth and going higher up ranks as a means take life easy and be lax. Secondly the idea premises itself with the idea that work inherently is undesirable and we should retire from it as early as possible. Although it is impossible to find direct answers to these modern issues from early protestant and puritan writings about the Protestant concept of work and vocation, it possible to answer these issues based on protestant and puritan principles such as sola scriptura. The Bible teaches that work is not a consequence of the fall that we have to find ways to redeem ourselves out off or retire from. It was God who gave humans the ability to do good creative and productive work, to build cities and civilization and joy to eat the fruit of one's labour is also a gift from God. As work is a part of God's original design in creation and not a result of the fall, there are good scriptural reasons to think work will remain in the heavenly city as well. By the necessity of work God also providentially secures his design to keep work as a part of human life, for 'if one shall not work one shall not eat' (2 Thess. 3:10). For if the ridiculous idea of working yourself enough prosperity and retiring from work to spend the rest of one's life holidaying was possible, the ones doing it now would be the richest people alive today, owning the biggest businesses. The fact they are not must teach us something. Nokia once dominated cell phone market in India [17]. Its Symbian phones found its place in almost every hand that held a cell phone. When your business is doing well, investors invest money to fuel your race against your competitors who are doing 
everything to tip you off the top. However when such leverage from previous success is not diligently used one could lose out and become debtors to all your investors. Android phones replaced the dominance [18] of Nokia phones and ended the story of Nokia in India with a sad note. All the monetary worth of the business is in the form of industry establishment which becomes irrelevant once replaced by innovation, new technology and change. Many historical examples can be given in view of this. Edison championed the DC technology. However when AC technology championed by Tesla replaced DC technology, Edison lost out but however moved onto other things [19]. Therefore it is never possible to retire fully from work; one could have retired from the wealthiest state's services with the best retirement benefits but if the state grows weak and is captured by an enemy state there is no state to pay your retirement benefits. Every day is a new day, with new changes by which God providentially secures the necessity of work to stay relevant and contribute useful, productive and meaningful work and by which we eat our food and give thanks to the one who both gives us the ability to work and gifts us with the gift of eating of the fruit of one's labour.

\section{References}

1. Ryken, L. (1995). Redeeming the time: a Christian approach to work and leisure. Grand Rapids, MI: Baker Books.

2. Frey, D. E. (1998). Individualist economic values and self-interest: The problem in the Puritan ethic. Journal of Business Ethics, 17(14), 1573-1580.

3. Aristote, 384-322 av. J.-C. (1988). The politics. Cambridge: Cambridge University Press.

4. Perkins, W. (1603). A treatise of the vocations, or, Callings of men, with the sorts and kinds of them, and the right vse thereof. London: Printed by Iohn Legat, printer to the Vniuersitie of Cambridge.

5. Urbainczyk, Theresa. Slave revolts in antiquity. Routledge, 2016.

6. Markoff, John. Abolition of Feudalism: Peasants, Lords, and Legislators in the French Revolution. Penn State Press, 2010.

7. Torvalds, L., \& Diamond, D. (2002). Just for fun: the story of an accidental revolutionary. New York, NY: HarperCollins.

8. Devine, F. (2009). Class practices: how parents help their children get good jobs. Cambridge: Cambridge University Press. 
9. Robinson, K., \& Aronica, L. (2010). The Element: how finding your passion changes everything. Camberwell, Vic.: Penguin.

10. Bainton, Roland Herbert. Here I stand: A life of Martin Luther. Abingdon Press, 2013.

11. Luther, Martin. The bondage of the will. Hendrickson Publishers, 2008.

12. Lloyd-Jones, David Martyn. Romans: An Exposition of Chapter 13: Life in Two Kingdoms. Banner of Truth Trust, 2002.

13. Maisels, C. K. (2016). Emergence of civilization: from hunting and gathering to agriculture, cities, and the state ... of the near east. Taylor \& Francis.

14. Moore, K. (2011, August 9). The Decline but Not Fall of Hierarchy -- What Young People Really Want. Retrieved from https://www.forbes.com/sites/karlmoore/2011/06/14/the-decline-but-not-fall-ofhierarchy-what-young-people-really-want/\#46a575a55843.

15. O'Shea, A. (2017, October 6). Millennials, Here's How To Retire By 40. Retrieved from https://www.forbes.com/sites/arielleoshea/2017/08/03/millennials-heres-how-toretire-by-40/\#2352cd1687f1.

16. Blomberg, Craig L. Christians in an Age of Wealth: A Biblical Theology of Stewardship. Zondervan Academic, 2013.

17. Malini Goyal \& Kamya. (2011, October 4). How Nokia fell from dominance and got pinned down by competitors. Retrieved from https://economictimes.indiatimes.com/tech/hardware/how-nokia-fell-fromdominance-and-got-pinned-down-bycompetitors/articleshow/7793841.cms?from=mdr).

18. Google found guilty of misusing Android dominance in India, CCI orders wider probe. (2019, June 28). Retrieved from https://www.businesstoday.in/technology/topstory/google-found-guilty-of-misusing-android-dominance-in-india-cci-orders-widerprobe/story/359814.html.

19. Jonnes, J. (2004). Empires of light Edison, Tesla, Westinghouse, and the race to electrify the world. New York: Random House. 